\title{
Effects of Integrating Literary Texts in Enhancing the Quality of Academic Writing of University Students in Bahrain
}

\author{
Fatima Talal Fakhroo ${ }^{1} \&$ Abdulaziz Mohammad Bulaila ${ }^{2}$ \\ ${ }^{1}$ Ministry of Education, Kingdom of Bahrain \\ ${ }^{2}$ Faculty of Arts, University of Bahrain, Kingdom of Bahrain \\ Correspondence: Fatima Talal Fakhroo, Ministry of Education, Kingdom of Bahrain. E-mail: \\ fakhroo86@gmail.com
}

Received: October 29, 2020

Accepted: December 9, $2020 \quad$ Online Published: December 22, 2020

doi:10.5539/ijel.v11n1p213

URL: https://doi.org/10.5539/ijel.v11n1p213

\begin{abstract}
The research explored the effects of integrating literary texts on the writing performance of selected university students. It also documented the attitudes of the university students on the integration of literary texts in their regular writing course and their perceptions on the difficulties they encounter in the writing process. These research objectives were rationalized by the need to address the writing difficulties by applying theoretical assumptions and addressing the empirical gaps of previous studies on the effectiveness of literature as a rich resource in developing language competence. The research participants were composed of first year business students who were enrolled in an ESP course in one of the universities in Bahrain. Each group was composed of 35 students with an equal distribution of male and female participants. A mixed method approach was used to address the core research questions with the primary application of an experimental design. The results revealed that literary text integration is effective in improving the academic writing performance of the university student-participants as indicated by the statistical test, wherein the experimental group $(\mathrm{m}=3.35)$ had a higher level of improvement than the control group $(\mathrm{m}=2.93)$ in terms of their overall writing performance after the intervention. The student-respondents had a positive attitude towards the integration of literary text in their regular writing course. Writing difficulties included the process of writing the introduction, body, conclusions of their academic writing tasks, use of relevant vocabulary communicative achievement, organization, and language use. It was recommended that language teachers should incorporate literary texts that are related to the writing lessons. Educational administrators and leaders may revisit the curriculum and use the empirical results in developing a more relevant language curriculum especially in the area of writing instruction where literary texts could be integrated.
\end{abstract}

Keywords: literature and writing performance, attitudes towards literature, impact of literary texts

\section{Introduction}

\subsection{The Research Problem and Its Rationale}

The role of literature to have potentials in language learning is acknowledged in several empirical, conceptual, and theoretical assumptions. At the theoretical and conceptual level, Krashen (1994) pointed out the necessity of using literature in enhancing the language skills of second language learners. This premise finds support in the Communicative Competence Model proposed by Cannale and Swine (1980), which proposes that communicative competence includes sociolinguistic competence along with linguistic and strategic competence that interact with each other. In other words, language learning involves not only the ability of a language learner to choose grammatically correct elements in forming sentences but also involves the learners' ability to know when, where, and how to use these elements in specific situations. Such theorization of language learning is anchored on the cognitive-functional linguistics framework supported by Halliday (1974) and Hymes (1972). Hence, using literature provides not only authentic language use but also personal involvement of the learners to use the language in meaningful ways, which is an essential factor in the attainment of communicative language competence.

Recent conceptualizations on the important role of literature in language learning support the aforementioned theoretical underpinnings. For example, Gasimova (2018) claimed that literature can be regarded as a rich source 
of authentic material because it conveys meaningful language in a fashion intended for native speakers and it is an aesthetic representation of the spoken language that goes beyond the artificial grammar of a classroom provided by textbooks. Similarly, Ildrimzade (2018) emphasized the use of literature as a popular technique for teaching basic language skills because it is an exciting and different approach to language learning that fully incorporates the teaching of grammar, reading, spelling, vocabulary, writing process, listening, thinking skills, and many other elements.

At the empirical level, previous findings from various studies also confirm the potentials of literature in English language classes and they indicate that the use of literature in language teaching enriches the learners' linguistic awareness and rhetorical structure of literary discourse (Nachmanovitch, 1990; Zyngier, 2006; Spiro, 2007; Van Peer, 2007). Related to these empirical evidences are the studies of Muthusamy, Mohamad, Ghazali, and Subrayan (2010) on how literature helps in developing the imagination of second language learners, Cheung, Tse and Tsang (2003) on the relationship between creativity and creative writing skills; and Coles (2015) on the potentials of literature in stimulating the creative imagination of students. This is also affirmed in different research such as the study of Adam and Babiker (2014) which tackled the role of English literature in enhancing creative writing skills, Martino and Sabato (2014) on the relationship between language and literature in educational contexts, Paran (2010) on the claims that teaching literature is embedded with various internal goals, Green (2010) on interaction of writing with the major literary works, and Zyngier (2006) on the significance of literature teaching in the acquisition of some cultural models in language learning.

In some empirical works, the role of literature has been pointed out to be effective when applied to language learning and teaching. This premise was emphasized in the studies of Weber-Feve (2009) on how the input-to-output approach can be combined in an introduction to literature course; Sivasubramaniam (2006) on the potentials of literature in developing vocabulary, grammar, and critical thinking skills of the language learners; Scott (2004) on the effect of literature on the grammar skills among French learners; Hanauer (2001) on how poetry can enhance the motivation and writing skills of different second language learners. Larkin (1983) argued that the stages of inspiration, creation, and recreation in the use of poetry as a form of literature in language classrooms should be explored by teachers and students.

In an experiential perspective, it can be observed that most language courses that are offered in various training institutes and universities in Bahrain give emphasis only on the various language competencies. These language programs are based on English for Specific Purposes (ESP) wherein literary materials are set aside because the main goal is to teach the students with the literal language and the non-literary aspects of communication as they are used in the various platforms of communication in different fields or disciplines such as in the field of engineering, information technology, and commerce. It is also observed that most students experience difficulties in writing.

This study was proposed because of the justifications mentioned in the preceding paragraphs. To put simply, the research was rationalized by the need to provide solutions to the reported and observed writing problems and difficulties experienced by many university students in the country, the recognized theoretical assumptions about language competence that links the use of literature and effective language learning, and the previous empirical findings on the positive impact of literature in many areas of language acquisition and learning. Hence, this study posited the following research questions:

1) What is the extent of effectiveness of literary text integration in improving the academic writing performance of the university student-participants?

2) What are the attitudes of the university student-participants on the integration of literary texts in their regular writing course and the difficulties they encounter in the writing process?

\subsection{Theoretical Underpinnings}

One of the relevant theories of the study is the Communicative Competence Model of Cannale and Swine (1980), which postulates that communicative competence involves many types of competences. They argued that the ability to convey message involves four various sub-competencies: sociolinguistic (skill to create appropriate utterances in specific social contexts), grammatical (capability to produce and generate grammatically correct utterances), strategic (capability to address communication issues as they arise) and discourse (capability to generate coherent and cohesive utterances).

From the aforesaid theoretical claim, it can be stated that Canale and Swain (1980) understood communicative competence as a synthesis of an important framework and paradigm of knowledge and skill needed for the communication of meanings. In their concept of communicative competence, knowledge refers to the (conscious 
or unconscious) understanding of a person about language and about other dimensions of language function. According to them, there are three kinds of knowledge: understanding of the supporting grammatical rules, understanding of how to perform language in a social setting in order to achieve communicative aspects, and the understanding of how to amalgamate utterances and communicative aspects in relation to discourse principles. In addition, their construct of skill pertains to how a person or language learner can utilize his understanding and knowledge in actual communication.

The relevance of the aforesaid theory to the present research is its emphasis on the other three competencies such as sociolinguistic (ability to produce sociolinguistically appropriate utterances), discourse (ability to produce coherent and cohesive utterances), and strategic (ability to solve communication problems as they arise). In the use of literature, the students are not only exposed to grammatical competence but also to sociolinguistic, discourse, and strategic competence. In other words, students who are not exposed to literature may lack the cultural experience that the target language provides. Hence, they may become weak in these three other aspects of competence because they only focused on grammatical competence which is more concerned with structures and rule patterns of the language.

\subsection{On the Effects of Literature on Writing Performance}

The effects of literature on the learners' cognition, language learning, and academic performance have been documented in previous studies. For example, in the work of Bloemert, Paran, Jansen and de Grift (2019), information supplied by a single open questionnaire were employed to explore the perspective and paradigm of Dutch secondary school students from 15 varied educational institutions with regards to the advantages of using literature education in their English as a foreign language (EFL) course. The same line of research objectives was proposed in Hismanoglu's (2005) research, which aimed at highlighting the usage of literature as an effective strategy for teaching basic language competencies such as reading, writing, listening and speaking and language areas. Michalko (2012) examined the impact of a specific strategy, which is the Spoken Word Poetry on the development of voice in writing. In the said research, data were obtained in varied ways which involved surveys, observations, interviews, and authentic work handed over by participants.

In a related research, Randolph (2014) examined the mechanisms of creative writing as part of literature which has not been utilized as a major element in English as a Second Language curriculum. This was also reflected in Setyowati's (2016) research, which intended to document the students' competency to construct opinion essay using flash fiction in the form of Frank Stocton's The Lady or the Tiger. In another important study, Schrijvers, Janssen, Fialho, and Rijlaarsdam (2016) examined the impact of literature integration on students' perceptions of themselves and the society. Corollary, an essential study on the impact of literature on the reader's interlanguage is that of Illingworth (2016). The said undertaking explored the possibility of utilizing poetry as a means of communication, by assessing the effectiveness of poetic verse as an alternative means of communication to other scientists.

It is important to note that Albalawi (2014) affirmed that teaching drama in his English subject influenced the development of the creative thinking skills among his intermediate students. In similar manner, Ntelioglou (2016) did a timely investigation of the impact of integrated drama/ESL lessons on second language learners' language skills. Another similar study is that of Cer (2017) who used a quasi-experimental method with pre-test and post-test in the control and the experimental groups. The said study applied a mixed method and affirmed that creative drama triggered the students to hone their writing skills; it recommended that creative drama can be used in an English class.

Adiguze (2015) stated that creative drama is a group activity. He further explained that it is dependent on the life experiences of the actors because it plays of utmost importance to the process and that it is based on acting. One of the most relevant research is that of Adam and Babiker (2014) because the role of literature teaching in enhancing creative writing was explored on the perspective of the teachers. The overt and explicit teaching of literature was also found to improve the language learners' usage of several literary devices such as figures of speech and other literary techniques.

In the report of Martino and Sabato (2014), the relationship between language and literature in educational contexts and textbooks devoted to the teaching of English as a foreign language through a literature-based approach was emphasized. Given this perspective, it is important to look into the proposition of Paran (2010) who claimed that teaching literature is embedded with various internal goals. This is because it entails the development of the individual in his affective and intellectual domains. This premise is supported by Green (2010) when he explained that the act of writing is like interacting with the major literary works. Zyngier (2006) also affirmed the premise that literature teaching enhances the acquisition of some cultural models which is 
important in language learning and teaching.

On a more pragmatic account, Weber-Fève (2009) addressed how an input-to-output approach can be combined in an introduction to literature course. This is corollary with the proposition of Sivasubramaniam (2006) who explained the potentials of literature in developing vocabulary, grammar, and critical thinking skills of the language learners. Several assumptions have also been made on the premise that teaching language through literature gives student motivation for learning. Scott (2004) affirmed the increase in grammar skills among French learners when they were given language classes that maximize the use of literary materials. Hanauer (2001) also asserted how poetry, which is a form of literature, can enhance the motivation and writing skills of different second language learners. On a related perspective, Krashen (1994) pointed out the necessity of using literature in enhancing the language skills of second language learners. This is supported by Larkin (1983) who argued that the stages of inspiration, creation, and recreation in the use of poetry as a form of literature in language classrooms should be explored by teachers and students.

In the research of Muthusamy et al. (2010), the role of literature in developing the creative writing skills and imagination of second language learners was investigated. Cheung et al. (2003) also confirmed the vital importance of using literature in teaching creative writing skills to foreign language learners in Hong Kong. The results of the two aforementioned studies are supported by Coles (2015) who argued that literature has the potential to improve the creativity and imagination of many individuals especially second language learners.

An important generalization is that most of these studies did not apply an experimental research design with a pure emphasis on the academic writing performance. For example, Adam and Babiker (2014), Weber-Fève (2009), Sivasubramaniam (2006), Scott (2004), and Hanauer (2001) only hypothesized on the impact of literature to general language skills. Another type of research gap that could be identified from the studies of Bloemert et al. (2019), Hismanoglu (2005), Michalko (2012), Randolph (2014), Setyowati (2016), Schrijvers et al. (2016), Illingworth (2016), and Albalawi (2014) is the use of both descriptive and correlational research designs. As noted in the current study, experimental design was opted instead of the former to provide another perspective of empirical data on the effectiveness of literature in language learning.

\subsection{On the Attitudes Towards Literature}

Because one of the major research objectives delves on the attitudes and perceptions of students on the use of literature in writing, several related studies on this topic were reviewed. One of these investigations was that of Alfauzan and Hussain (2016) who studied the attitude and perception of Saudi undergraduate students towards English literature courses. The said study affirmed that the learners' environment significantly contributed to the formulation of positive attitudes and to their perception towards literature and their desire to improve their writing skills in the target language. Another investigation was conducted by Al-Mahrooqi and Al-Wahaibi (2012) on the English majors' attitudes towards literature courses at a higher education institution in Oman. It attempted to cite the similarities between their perceptions of the challenges they face when taking these courses and those of their professors towards these challenges.

In Malaysia, the integration of literature in language education was the focus of a similar study conducted by Baba (2008). It primarily analyzed the attitudes of both teachers and students towards literature and its use in language teaching in the context of English as a Second Language. Another parallel research was conducted by Awang and Kasuma (2015) on high school students' perceptions of their motivations and attitudes towards the learning of English literature component of a specific syllabus. The impact of teaching simple literary texts in university classes on the students' attitudes towards their L2 was the focus of another parallel research conducted by Khatib and Askari (2012).

The teaching benefits and possible consequences of using literary texts were discussed in a study conducted by Tesdovska's (2016). One of the findings showed that majority of the respondents prefer prose to poetic materials. From the findings, it could safely be deduced that topics of relevance to the language learners boost their interest and encourage their involvement. Bloemert, Paran, Jansen, and de Grift (2019) conducted a study on the viewpoint of Dutch high school students from 15 different schools with regards to the advantages of literary education in English as a foreign language (EFL). To see how exposing students to short stories affects motivation in foreign language learning and attitude towards English literature was the aim of the study conducted by Shirzadi and Moheimany (2018). It was affirmed that young Iranian EFL students were highly motivated to learn the target language using short stories.

In the study of Fakhroo (2017), the role of literature in enhancing creative writing as viewed by both UOB teachers and students was investigated. The findings of the study indicated that the highest percentage of agreement for teacher-respondents is reflected in terms of their view on the role of literature in developing 
creative writing and creative imagination (84\%), while the lowest percentage of agreement for student-respondents was reflected in terms of their views and opinions on the activities and approaches that can be used by literature teachers to develop creative writing (67.2\%).

The aforesaid studies supported the positive attitude of various learners towards the use of literature. Nonetheless, most of the studies reviewed in this section pertaining to the attitude of the learners were based on purely descriptive methods. In other words, the participants in their research did not participate in a pure experimental research. Eliciting data on the students' attitude who participated in an experimental research could affirm the generalizability of the findings reflected in these studies. As such, the current study interviewed student-participants in the experimental group in terms of their actual attitude towards literary text integration.

\subsection{On Perceptions of Writing Difficulties}

There are several studies that affirmed the pervasiveness of difficulties and challenges that different second and foreign language learners experience when they are faced with the writing task. Ismail (2010) investigated the students' perceptions of both general writing and academic writing course (AWC). The results revealed the respondents' positive perceptions toward ESL writing in general and the AWC course. Another investigation on the academic writing challenges of ESL learners was taken by Al Badi (2015). One of the findings revealed that the respondents tended to have similar difficulties in academic writing regardless of their previous educational backgrounds. The most common of which was related to language use as well as coherence and cohesion.

A survey on 50 Master of Arts students in English who were part of the new English for Academic Purposes (EAP) program at a university in South China was conducted by Cai (2013). Aside from the survey, a focus group interview with a smaller group was also done to enhance the investigation. Looking into some difficulties that university students would encounter when they write in English as a Foreign Language (EFL) was the aim of the study conducted by Ibnian (2017). Also aimed at proposing practical solutions to help EFL learners overcome their writing fears, the investigation involved eighty-two English majors from the World Islamic Sciences and Education University in Jordan.

A study on the perception of Yemeni students towards the types of errors of academic writing at Hadhramout University - College of Education was conducted by Al Tamimi (2018). It revealed that students committed a lot of errors in their academic writing in relation to sentence structure, vocabulary, and expressing ideas, and the use of punctuation, prepositions, spelling, articles, and irregular verbs. Al Mukdad (2019) in a recent study focused on the academic writing problems encountered by students at Arab International University (AIU) who were taking the Academic Writing module (AWR). Results revealed that the respondents seemed to view all aspects of academic writing to be difficult.

The Palestinian EFL students' attitudes towards writing in general and their feelings between expressing ideas while writing in English and Arabic were examined in a research conducted by Jabali's (2018). Ariyanti and Fitriana (2018) had a parallel investigation on the problems encountered by EFL students in writing essays as well as discovering or identifying their learning needs to produce better English compositions. To determine the students' views of the problems they would normally encounter in their writing tasks was the sole aim of Ceylan's (2019) investigation. Using a descriptive-qualitative research, Pablo and Lasten (2018) identified and analyzed the difficulties of Senior High School students in writing academic essays and the overall quality of the academic essays of the students. The problems concerning English language writing and writing strategies among undergraduate students in Thailand were the sole aim of Boonyarattanasoontorn's (2017) study. Lalam (2018) conducted a parallel study that aimed primarily at identifying the problems encountered by EFL learners in essay writing. Al Mubarak (2017) conducted a research on the various challenges encountered by students learning English as a Second Language (ESL) in their academic writing. Saudi students' perceptions of academic writing were the focus of Alhojailan's (2015) research. Finally, a parallel investigation on the English language writing in a Saudi university context was conducted by Alkubaidi (2017).

Albeit the aforesaid studies explored the difficulties of language learners in the process of writing, most of these studies did not combine two methods of eliciting data. These studies focused on purely content analysis technique wherein they looked into the actual writing of the students and identified their mistakes which were considered difficulties. These included the studies of Ismail (2010), Al Badi (2015), Cai (2013), and Ibnian (2017). The problem with just looking at the mistakes of the students and considering them as a difficulty is that sometimes these mistakes are just errors and not deliberate. Hence, the current study applied the element of introspection wherein the students were also interviewed on their perception of the difficulties they experience in writing. Combining both content analysis and introspection through interviews was imperative to address the aforesaid research gaps. 


\section{Method}

\subsection{Research Design and Approach}

This study utilized qualitative and quantitative research approaches to address the research questions in a comprehensive manner. Quantitative research approach addressed the research problem that involved statistical data. This included the research objectives of analyzing the quantitative profile of academic writing performance of the control and experimental groups before and after the experiment, determining the significant improvement in the writing performance of the experimental group after the experiment and verifying the assumption that the writing performance of the experimental group is higher than the writing performance of the control group. The qualitative research approach was also deemed necessary in the description of the attitudes of the studentrespondents on the integration of literary texts in the teaching of writing and the perceived difficulties encountered by the students in the process of completing and performing the writing task.

In terms of research design, the combination of descriptive and experimental research designs was implemented to provide answers to the relevant research questions. It is evident that an experimental design was necessary in answering the first research question on the effects of the integration of literary texts on the academic writing performance of the students. A pretest was administered first to both groups which was followed by an experimental phase wherein the control group did not receive the intervention while the experimental group received the intervention involving the literature integration teaching. After the specified period of administering the intervention in the experimental phase, a posttest was administered to both groups and the results of both groups were compared to verify which group obtained a significantly higher level of academic writing performance.

\subsection{The Sample and the Research Participants}

The study was conducted in a university in Bahrain. Research participants were composed of first year business students who were enrolled in an ESP course in the second semester. The said criteria included the number of students for the experimental and control groups, gender distribution, enrollment in a business English course. Each group was composed of 35 students with an equal distribution of male and female students. In terms of demographic background, the student-participants in each group were 18-20 years old, residing in different governorates of the country, and Bahrainis in terms of nationality at the time of the experiment.

The course emphasis was on reading skills, vocabulary building, grammar, and writing in a business context. The said course aimed to improve and develop students' language skills to enable them to communicate effectively in various business contexts. As noted, the student-respondents belonged to the College of Business Administration of the university, which has the vision to achieve excellence through strong leadership in business education locally, regionally, and internationally.

It must be noted that three language teachers also participated in this study to assess the writing performance of the students in both groups. The language teachers were chosen by the researcher to ensure reliability and generalizability in the ratings which were the basis in verifying the research hypotheses. The criteria in selecting the three language teacher-evaluators included having at least a master's degree in language instruction and a teaching experience of at least 10 years. Inter-rater reliability test was not applied in their ratings since the marking process of students' output was preceded by a moderation meeting. There was also a follow-up deliberation meeting after all marks were tabulated. It must be noted that although inter-rater reliability test is an objective measure, there are also limitations to simply relying on this single approach.

\subsection{Research Instruments}

The research instruments were divided into two: the qualitative research instruments and quantitative research instruments. The qualitative research instrument was composed of the Interview Questions on the Attitudes towards Integrating Literature in the Writing Class and the Perception on their Writing Difficulties, which aimed to document and describe the qualitative profile of the control and experimental. This primarily focused on the difficulties encountered by the student-respondents in terms of their academic writing. It also included the attitudes of the experimental group towards the use of literary texts in the teaching of writing.

To further verify the difficulties of the participants in writing, the use of content analysis techniques was employed as an auxiliary technique to pinpoint the observable difficulties in their written output. The quantitative research instrument was composed of two sets. The first set was the Writing Test, which was administered to both groups before and after the experiment. The Writing Rubrics was another component of this set which was used to rate objectively the writing performance of the students in both groups. As mentioned earlier, the three language teachers rated the academic writing outputs of the students with the use of the writing 
rubrics. The writing rubrics was based on Cambridge English (2014) composition writing rubrics. Hence, there was no need to do pilot testing in terms of this writing rubrics because it was based on a standard framework.

\subsection{The Experiment}

Since this was an experimental research, certain steps needed to be taken into consideration. The major steps included the matching process, pretest administration, actual experimentation such as the application of the literature integration teaching in the experimental group, posttest administration, and comparison of results.

The matching process was vital in ensuring the external validity of the research. In this phase of the experiment, the student-participants in both groups were chosen in such a way that both groups had the same characteristics, or otherwise called as a matched group. This is what makes experimental research different from other research designs because in experimental research, both groups are matched. In order to do the matching, the parameters described in the research respondents' section were followed.

After the students in both the experimental and control groups had been matched, the pretest in writing was administered. The result of the pretest was compared with the posttest after the experiment. In administering the experiment, both groups took the exam at the same time to control the threats to external validity. After the pretest, both groups received different methods of teaching for a period of 8-10 weeks. The control group followed the traditional method of teaching ESP which did not integrate any forms of literary work or literature in a specific teaching-learning episode. The experimental group received the literature integration teaching at the start of every session. Examples of literary works used in this experimental research were some quotations; "Farmer Jones and His Wife"; "Obligation" excerpt in Hamlet, which is a play by William Shakespeare; "Mystery Red Truck", and "Death of a Salesman" by Arthur Miller.

This means that literature or certain elements of a literary work were used in the first 10-15 minutes of the sessions. This was possible by using the theme of the ESP lessons as a bridge to the theme of a literary work. In other words, only certain elements of a literary work were used and not the entirety of it in the preparation or introductory part of a lesson. For example, in the lesson about writing a business letter of complaint of a particular product, the teacher used a section of a literary work that tackled the same situation wherein the character in the story complained about something he/she bought from a merchant. This situation was used as an incitation for the students to share their personal involvement with the theme of the ESP lesson.

After the 8-10 weeks of teaching different methods to both the groups, the posttest was administered to them. The results of the posttest were compared with the results of the pretest to verify the effects of the research intervention, which was the literature integration teaching. Inherently, the posttest had the same structure with the pretest because the same skill was measured with the use of a similar task, which was to write an email. The posttest had also the same time duration but with the use of a different topic to avoid memory effect. In order to statistically compare the results, the use of statistical tools was opted.

At the end of the experiment, the researcher interviewed the student-participants to explore their qualitative accounts in terms of their attitudes towards literature integration and the difficulties experienced when faced with a writing task. This qualitative data was expected to support the quantitative findings of the study. In other words, the qualitative interviews were used as a complementary data gathering technique only in this regard to enrich the interpretation of findings. The content analysis on the types of mistakes reflected in the written output samples of the student-participants was also employed as an auxiliary technique and not a primary data gathering strategy.

\subsection{Analysis of Data}

Interview data were not subjected to any statistical test. Instead, the researcher used the descriptive accounts as a supplementary data in the interpretation of results. However, the quantitative aspects needed certain statistical tools. Descriptive statistics in the form of the mean score was used in addressing the research question that focused on the analysis of the quantitative profile of academic writing performance of the control and experimental groups before and after the experiment. This means that to summarize the information obtained from the experimental process, the mean score was computed to reveal the average of the quantitative writing profile of the research participants. In more specific premise, the ratings of the student-participants as rated by three language teacher-assessors based on the writing rubrics were summarized by getting the mean score, which became the basis for inferential statistical analysis. The mean score was used instead of percentages because there was an equal number of participants in both experimental and control groups.

The T-Test for Dependent and Independent Samples are inferential types of statistics which were used in addressing research question and verifying the hypotheses that involved the process of determining the 
significant improvement in the writing performance of the experimental group after the experiment and the process of verifying the assumption that the writing performance of the experimental group is higher than the writing performance of the control group.

At the end of the experiment, the researcher interviewed the student-participants to explore their qualitative accounts in terms of their attitudes towards literature integration and the difficulties experienced when faced with a writing task. This qualitative data supported the quantitative findings of the study. The content analysis on the types of mistakes reflected in the written output samples of the student- participants was also employed as an auxiliary technique and not a primary data gathering strategy.

\section{Results}

\subsection{Quantitative Writing Profile}

This section addresses the first research question on the quantitative profile of the research participants in terms of their writing performance. As depicted in Table 1, the experimental group $(\mathrm{m}=3.35)$ had higher level of improvement than the control group $(\mathrm{m}=2.93)$ in terms of their overall writing performance, with a differential value of .42 . The experimental group $(\mathrm{m}=3.46)$ also had higher level of improvement than the control group $(\mathrm{m}$ $=3.0$ ) in terms of the content aspect of their writing performance, with a differential value of 46 .

Table 1 also reveals that the experimental group $(\mathrm{m}=3.42)$ had higher level of improvement than the control group $(\mathrm{m}=3.14)$ in terms of the communication achievement aspect of their writing performance, with a differential value of .28 . The experimental group $(\mathrm{m}=3.48)$ had higher level of improvement than the control group $(\mathrm{m}=2.92)$ in terms of the organization aspect of their writing performance, with a differential value of .56. In terms of the language, the experimental group $(\mathrm{m}=3.05)$ had higher level of improvement than the control group $(\mathrm{m}=2.67)$, with a differential value of .38 .

Table 1. Differences in the posttest writing performance of the experimental and control groups

\begin{tabular}{|c|c|c|c|c|c|c|}
\hline \multirow[t]{2}{*}{ Writing Categories } & \multicolumn{2}{|l|}{ Posttest } & \multirow{2}{*}{$\begin{array}{l}\text { Differential Value of } \\
\text { Improvement }\end{array}$} & \multirow[t]{2}{*}{ T-Value } & \multirow[t]{2}{*}{ P-Value } & \multirow[t]{2}{*}{ Interpretation } \\
\hline & Control & Exp. & & & & \\
\hline Organization & 2.92 & 3.48 & .56 & 17.66 & .000 & Significant \\
\hline Content & 3.0 & 3.46 & .46 & 11.50 & .000 & Significant \\
\hline Language & 2.67 & 3.05 & .38 & 9.02 & .000 & Significant \\
\hline Communicative Achievement & 3.14 & 3.42 & .28 & 6.16 & .000 & Significant \\
\hline Overall & 2.93 & 3.35 & .42 & 250.66 & .000 & Significant \\
\hline
\end{tabular}

Note. Level of Significance: .05.

The experimental and control groups had the biggest differential mean value in terms of the organization aspect (.56) of writing performance. This was followed by the content aspect of their writing performance, which was indicated by the differential mean value of .46 between the control and experimental groups in their posttest results. It is evident from the table that the experimental and control groups had the third biggest differential mean value in terms of the language use aspect (.38) of writing performance.

As seen Table 1, the experimental group made a significantly higher level of improvement than the control group in terms of their overall writing performance, which is indicated by the t-value of 250.66 with a p-value of .000 that is lower than .05 level of significance. It is also depicted in the table that the experimental group made a significantly higher level of improvement than the control group in terms of the content aspect of their writing performance, which is indicated by the t-value of 11.50 with a p-value of .000 that is lower than .05 level of significance. The experimental group also made a significantly higher level of improvement than the control group in terms of the communicative achievement aspect of their writing performance, which is indicated by the $\mathrm{t}$-value of 6.16 with a p-value of .000 that is lower than .05 level of significance.

Indicated by the t-value of 17.66 with a p-value of .000 that is lower than .05 level of significance, the experimental group made a significantly higher level of improvement than the control group in terms of the organization aspect of their writing performance. In the same manner, the experimental group made a significantly higher level of improvement than the control group in terms of the language use aspect of their writing performance, which is indicated by the t-value of 9.02 with a p-value of .000 that is lower than .05 level of significance.

\subsection{Qualitative Writing Profile}

This section reflects the qualitative data obtained from the research participants. It specifically includes the 
accounts and narrative description of the students' difficulties in writing and their attitude towards writing process and the integration of literary text in the writing class.

\subsubsection{Writing Difficulties of the Respondents}

The information in Table 2 summarizes the common response of the student-participants in terms of their writing difficulties. As gleaned from the table, the most common difficulties in writing the introduction are writing the thesis statement, starting with the first sentence, and starting the introductory paragraph. Writing the topic sentence, starting a new body paragraph, separating one paragraph from another paragraph, and listing down details to support the paragraph are the common difficulties reported by the participants in terms of writing the body of the written output.

Table 2. Summary of common qualitative responses of the student-participants in terms of writing difficulties

\begin{tabular}{|c|c|}
\hline Interview Questions & Common Themes/Response \\
\hline $\begin{array}{l}\text { Is writing the introduction of an academic essay difficult? If yes, } \\
\text { what specific areas in the introduction is difficult to write? }\end{array}$ & $\begin{array}{l}\text { writing the thesis statement, starting with the first sentence, starting the } \\
\text { introductory paragraph }\end{array}$ \\
\hline $\begin{array}{l}\text { What areas in the body of an academic essay difficult to write for } \\
\text { you? }\end{array}$ & $\begin{array}{l}\text { writing the topic sentence, starting a new body paragraph, separating one } \\
\text { paragraph from another paragraph, listing down details to support the paragraph }\end{array}$ \\
\hline Is writing the conclusion difficult? Why? & $\begin{array}{l}\text { difficulty in starting the first sentence of the conclusion, summarizing the points, } \\
\text { writing some sentences in the conclusion }\end{array}$ \\
\hline \multicolumn{2}{|c|}{ What can you say about your vocabulary and grammar in writing? tenses, subject-verb agreement, writing different sentence types } \\
\hline \multicolumn{2}{|l|}{ Do you think you are good at these aspects? } \\
\hline \multicolumn{2}{|c|}{ Is organizing the different paragraphs difficult? Why do you say so?writing the main ideas; writing sentences to support the main idea } \\
\hline $\begin{array}{l}\text { How will you rate yourself in terms of spelling and punctuation } \\
\text { when it comes to writing an academic essay? }\end{array}$ & some punctuation errors, use of colon and semi-colon, spelling difficulties \\
\hline
\end{tabular}

Based on the interview with the research participants, the most common difficulties in writing the conclusion included difficulty in starting the first sentence of the conclusion, summarizing the points, and writing some sentences in the conclusion. Based on the results of the interview, the student-participants commonly encounter difficulties in the use of tenses, subject-verb agreement, and writing different sentence types. Some of them also reported that they find it challenging to write the main ideas and writing sentences to support the main idea. A few of them reported that they have problems on the use of some punctuation such as colon and semi-colon.

\subsubsection{Attitude Towards the Use of Literary Texts in Developing Academic Writing Skills}

The students in this experimental research proposed several ways on how to improve their writing skills, which could be effective in the context of their learning styles and background as a learner. One of the ways in improving their writing skills is guided writing practice. In one of the accounts of the student-respondents, the use of guided writing practice was proposed because he believes that it could help him overcome the difficulties in the writing process. With the teacher's guidance in the actual writing task, he is directed on the appropriate organization, lexical choices, and the language usage needed to complete the required output.

Another student suggested that the use of stories and interesting excerpts of literary works helps her to be more focused in the writing process. This is because of the insights that the stories and other forms of literary works provide as a springboard in the writing task. She explained that when she reads a story in relation to the writing task such as the "Mystery Truck", her mind is exposed to different conceptual opportunities on how to commence with the writing task. Few verses from poem related to the academic writing task could inspire her to write the subtasks of the required output.

The use of literary texts before starting a writing task is supported by one of the student-participants in this research. She said that it takes away her boredom from the monotony of the technicalities of her field of specialization. The stories and the pieces of wisdom that the literary texts provide are good starting point in the actual writing task. They also keep her going with the different bottlenecks of the task. She explained that these literary excerpts are useful tools in generating ideas and concepts needed in the writing process. Using these texts along with the official technical texts could result to an effective multidisciplinary integration.

One of the students in the experimental group disclosed that she enjoyed every session whenever her teacher uses a literary work excerpt at the start of the lesson for the first 10-15 minutes before going to the main activities such as "Success is Counted Sweetest". She said that she was looking forward to every surprise during her sessions with her language teacher. Another student also enjoyed the inspiration that each literary piece 
provides in the various sessions of his English 146 class.

\section{Discussion}

The aforesaid findings are supported by the empirical works reviewed in this research. For example, the significant improvement on the academic writing performance of the experimental group who was exposed to literary texts at the start of their English classes finds empirical support in the study of Bloemert et al. (2019), Hismanoglu (2005), Michalko (2012), Randolph (2014), Setyowati (2016), Schrijvers et al. (2016), Illingworth (2016), Albalawi (2014), Ntelioglou (2016), Cer (2017), Adiguze (2015), and Adam and Babiker (2014). These studies also affirmed the significant effects of literature in enhancing language learning potentials among second and foreign language learners. In the same manner, Adam and Babiker (2014), Weber-Fève (2009), Sivasubramaniam (2006), Scott and (2004), Hanauer (2001) also averred the importance of literature in the development of creativity which is an essential aspect in the writing process.

It is apparent that the findings of the present study are similar to the results of the previous studies on the positive effect of literature on the writing performance of language learners. The only difference was that the present study used a different writing rubric to measure the gains in writing performance, thereby providing a more detailed analysis of the variable. The said results are important to note since they add to the existing knowledge related to the role of literature on the writing performance of second language learners. Foremost, it affirmed the theoretical underpinnings of Halliday (1974), Hymes (1972), Krashen (1994), and Cannale and Swine (1980). The present study also contributed in a unique manner since it addressed some research gaps by clarifying whether literature could be used in the context of English for Specific Purposes courses such as the English for Business.

Another salient feature of the present research which makes its contributions different from the previous studies is that it investigated the specific use of a literary piece in a specific phase in a teaching session by applying literature only in the introductory part of the lesson and not the entire lesson. This study also addressed some methodological gaps because it used an experimental research design, which was rarely used in previous studies involving the dependent variable of academic writing.

In terms of the attitudes towards literature as a resource material in language learning, the current study revealed that the students in the experimental group enjoyed such sessions. The findings on the positive attitude of the language learners on the use of literary texts and devices in language learning also find support in the results of the study of Alfauzan and Hussain (2016), Al-Mahrooqi and Al-Wahaibi (2012), Baba (2008), Awang and Kasuma (2015), Khatib and Askari (2012), Bloemert et al. (2019), Shirzadi and Moheimany (2018), and Fakhroo (2017). Nonetheless, some of these studies affirmed that few language learners have varying attitudes towards the use of literature in language classes but most of the language learners had positive attitudes towards literature in their language classes because it inspires them to learn the language and allows them to express their meanings in different contexts.

In general, the research participants' attitude towards literature were all positive. Unlike previous studies, the current study noted a uniform positive trend on the use of literature in the experimental group. One evident themes that can be drawn from the qualitative responses of the respondents was enjoyment and meaningfulness when it comes to the use literary texts in their business writing course. This is supported by Gasimova (2018) who claimed that literature can be regarded as a rich source of authentic material because it conveys meaningful language intended for native speakers because it is an aesthetic representation of the spoken language that goes beyond the artificial grammar of a classroom provided by textbooks. Similarly, Ildrimzade (2018) also emphasized the use of literature as a popular technique for teaching basic language skills. It is an exciting and different approach to language learning that fully incorporates the teaching of grammar, reading, spelling, vocabulary, writing process, listening, thinking skills, and many other elements.

The perceived difficulties in writing of the student-respondents also represent the challenges discovered in other empirical studies. In other words, the difficulties in writing revealed in this study were also seen in previous empirical works such as in the research of Ismail (2010), Cai (2013), Al Badi (2015), Alhojailan (2015), Ibnian (2017), Al Mubarak (2017), Alkubaidi (2017), Al Tamimi (2018), Jabali (2018), Lalam (2018), Pablo and Lasten (2018), Ariyanti and Fitriana (2018), Ceylan (2019), and Al Mukdad (2019). These difficulties in writing range from the structural to organization difficulties.

In terms of the quantitative profile, it was affirmed in the research that the overall writing performance of both groups before the experiment was seen to be at the fair level. The strongest aspects in the writing performance was in terms of communicative achievement. Both the experimental and control groups obtained a satisfactory level of overall writing performance after the experiment. The research participants experienced problems in 
relation to writing the introduction, body, and conclusions of their academic writing tasks. Other common reported difficulties in writing were the use of relevant vocabulary, communicative achievement, organization, and language use. Qualitative responses related to the respondents' perception on the importance of writing varied such as their attitudinal profile in towards writing, strategies applied in writing tasks, and proposed strategies to improve their writing skills. Nonetheless, all the student-participants in the experimental group had a positive attitude towards the use of literature in the teaching of writing. The experimental group $(\mathrm{m}=3.35)$ had a higher level of improvement than the control group. The study also accepted the research hypotheses on the significant improvement in the writing performance of the experimental group after the experiment and the hypothesis stating that the writing performance of the experimental group is higher than the writing performance of the control group.

The findings imply that language teachers should try to incorporate literary texts that are related to the writing lessons that they are teaching because of the multifarious benefits that it provides to the learners in terms of their creativity and organization of ideas and arguments that are necessary in the writing process. Educational administrators and leaders may revisit the curriculum and use the empirical results of studies in developing a more relevant language curriculum especially in the area of writing instruction where literary excerpts could be integrated. Language learners may continue to be exposed to different literary works that are already available in their educational communities because these texts provide a cultural universe that is essential in the development of both sociolinguistic and strategic competence of the language learners. Future research on the effects of literature integration on the writing performance of students may use a more qualitative approach in order to present a rich discussion of the various variables associated with these elements.

\section{Acknowledgments}

I would like to express my sincerest gratitude to my research professor, Dr. Abdulaziz Bulaila, for all the professional expertise and the encouragements he has shown me. It inspired me to complete this humble work despite the daunting experiences of conducting an empirical research, my hectic schedule at the Ministry of Education, and my demanding role as a mother and wife. With exceeding enthusiasm and eagerness, I also aver my thanks to the thesis committee and examiners: Dr. Martin Parker, Dr. Nuri, Dr. Madani Othman, and Dr. Nouri Ageli. This research would not have been completed without their support and professional constructive feedback to me in my quest to complete a valid and reliable research output related to language teaching and learning. The Ministry of Education, its minister, and the government of the Kingdom of Bahrain are worthy of my deepest gratitude because without their support, this empirical endeavor would not have been operationalized. These institutions have provided me with various resources to do the legwork and other logistics needed in the study.

\section{References}

Adam, A., \& Babiker, Y. O. (2014). The role of literature in enhancing creative writing from teachers' perspectives. English Language and Literature Studies, 5(1), 109-118. https://doi.org/10.5539/ells.v5n1p109

Adiguze, O. (2017). Creative drama in education (10th ed.). Ankara: Pegem Academy.

Al Badi, I. (2015). Academic writing difficulties of ESL learners. Retrieved from https://www.westeastinstitute.com/wp-content/uploads/2015/02/Ibtisam-Ali-Hassan-Al-Badi-full-Paper.pdf

Al Mubarak, A. (2017). An investigation of academic writing problems level faced by undergraduate students at Al Imam Al Mahdi University, Sudan. English Review: Journal of English Education, 5(2). https://doi.org/10.25134/erjee.v5i2.533

Al Mukdad, S. (2019). Investigating English academic writing problems encountered by Arab International University Students. Theory and Practice in Language Studies, 9(3), 300-306. https://doi.org/10.17507/tpls.0903.07

Al Tamimi, N. (2018). An investigation of academic writing errors among tertiary level students at Hadhramout University: A perception study. Journal of Applied Linguistics and Language Research, 5(2), 214-227.

Al-Mahrooqi, R., \& Al-Wahaibi, T. (2012). EFL student attitudes towards studying literature at a higher education institution in Oman. European Journal of Social Sciences, 32(1), 77-83.

Albalawi, B. (2014). Effectiveness of teaching English subject using drama on the development of students' creative thinking. Journal of Research \& Method in Education, 4(6), 54-63. https://doi.org/10.9790/7388-04615463 
Alfauzan, A., \& Hussain, A. (2016). Attitude towards and perception of literature in EFL Setting: A Case Study on QU male undergraduate students. English Language Teaching, 10(1), 1-17. https://doi.org/10.5539/elt.v10n1p1

Alhojailan, A. (2015). Perception of academic writing by some Saudi graduate students in American universities. Retrieved

from https://shareok.org/bitstream/handle/11244/45334/Alhojailan_okstate_0664D_14134.pdf?sequence=1\&isAl lowed $=\mathrm{y}>$

Ariyanti, A., \& Fitriana, R. (2018). EFL students' difficulties and needs in essay writing. Advances in Social Science, Education and Humanities Research (ASSEHR), 158(1), 111-121.

Awang, Z., \& Kasuma, S. (2015). A study on secondary school students' perceptions of their motivation and attitude towards learning the English literature component. Retrieved from http://eprints.utm.my/id/eprint/10716/1/A_Study_On_Secondary_School_Students.pdf

Baba, W. (2008). An investigation into teachers' and students' attitudes towards literature and its use in ESL classrooms: A case study at matriculation centre in Malyssia. Retrieved from https://pdfs.semanticscholar.org/05f2/30b9d81a3fa7efb6fb43df4fbdefb50e671d.pdf

Bloemert, J., Paran, A., Jansen, E., \& de Grift, E. (2019) Students' perspective on the benefits of EFL literature education. The Language Learning Journal, 47(3), 371-384. https://doi.org/10.1080/09571736.2017.1298149

Boonyarattanasoontorn, P. (2017). An investigation of Thai students' English language writing difficulties and their use of writing strategies. Journal of Advanced Research in Social Sciences and Humanities, 2(2), 111-118. https://doi.org/10.26500/JARSSH-02-2017-0205

Cai, L. (2013). Students' perceptions of academic writing: A needs analysis of EAP in China. Language Education in Asia, 4(1), 5-22. https://doi.org/10.5746/LEiA/13/V4/I1/A2/Cai

Cambridge English. (2014). Assessing writing performance - B1 level. Retrieved from https://www.cambridgeenglish.org/../231794-cambridge-english-assessing-writing-performance

Cannale, M., \& Swain, M. (1980). Theoretical bases for communicative approaches to language teaching and testing. Applied Linguistics, 1(1), 1-47. https://doi.org/10.1093/applin/1.1.1

Cer, E. (2017). The Effects of Creative Drama on Developing Primary School Pupils' Writing Skills. https://doi.org/10.15390/EB.2017.7015

Ceylan, O. N. (2019). Student perceptions of difficulties in Second Language Writing. Journal of Language and Linguistic Studies, 15(1), 151-157. https://doi.org/10.17263/jlls.547683

Cheung, W., Tse, S., \& Tsang, H. (2003). Teaching creative writing skills to primary school children in Hong Kong: Discordance between the views and practices of language teachers. Publication of the Creative Education Foundation, 37(2), 77-98. https://doi.org/10.1002/j.2162-6057.2003.tb00827.x

Coles, W. (2015). Imagination and creativity in literary stories: A guide for writers. Retrieved from $\mathrm{http}$ //fictioneditorsopinions.com/2015/08/imagination-and-creativity-in-literary-stories-a-guide-forwriters

Gasimova, S. A. (2018). The role of literature in teaching and learning English. Web Scholar, 3(21), 24-26.

Green, A. (2010). Creative writing in A level English literature. NWE Writing, 2(1), 187-195. https://doi.org/10.1080/14790720903556155

Grey, S., Williams, J. N., \& Rebuschat, P. (2014). Incidental exposure and L3 learning of morphosyntax. Studies in Second Language Acquisition, 36(1), 1-34. https://doi.org/10.1017/S0272263113000727

Halliday, M. (1974). Explorations in the functions of language. London: Edward Arnold.

Hanauer, D. (2001). The task of poetry reading and second language learning. Applied Linguistics, 22(3), 295-323. https://doi.org/10.1093/applin/22.3.295

Hismanoglu, M. (2005). Teaching English through literature. Journal of Language and Linguistic Studies, 1(2), $53-66$.

Hymes, D. (1972). On communicative competence. In J. B. Pride \& J. Holmes (Eds.), Sociolinguistics Selected Readings (pp. 269-293). Harmondsworth: Penguin Books.

Ibnian, S. (2017). Writing difficulties encountered by Jordanian EFL learners. Asian Journal of Humanities and 
Social Studies, 5(3), 197-206.

Ildrimzade, L. J. (2018). The role of literature in teaching and learning language skills. World Science, 3(31), $39-41$.

Illingworth, S. (2016). Are scientific abstracts written in poetic verse an effective representation of the underlying research? https://doi.org/10.12688/f1000research.7783.1

Ismail, S. (2010). Exploring students' perceptions of ESL writing. English Language Teaching, 4(1), 10-21.

Jabali, O. (2018). Students' attitudes towards EFL university writing: A case study at An-Najah National University, Palestine. Heliyon, 4(11), 33-45. https://doi.org/10.1016/j.heliyon.2018.e00896

Jasmijn, B., Amos, P., Ellen, J., \& van de Grift, W. (2019) Students' perspective on the benefits of EFL literature education. The Language Learning Journal, 47(3), 371-384 https://doi.org/10.1080/09571736.2017.1298149

Khatib, M., \& Askari, H. (2012). A study of the effects of teaching literature on improving students' second language attitudes. International Journal of Applied Linguistics and English Literature, 1(4), 23-34. https://doi.org/10.7575/ijalel.v.1n.4p.37

Krashen, S. (1994). The input hypothesis and its rivals. In N. Ellis (Ed.), Implicit and explicit learning of languages (pp. 45-77). London, England: Academic Press.

Lalam, E. (2018). Essay writing difficulties encountered by EFL learners. Munich, GRIN Verlag. Retrieved from https://www.gr in.c om/doc ument/457637

Larkin, P. (1983). The pleasure principle. London: Faber \& Faber.

Martino, E. D., \& Sabato, B. D. (2014). Studying language through literature: An old perspective revisited and something more. Newcastle-upon-Tyne, UK: Cambridge Scholars Publishing.

Michalko, K. (2012). The effect of spoken word poetry on the development of voice in writing. Retrieved from https://fisherpub.sjfc.edu/education_ETD_masters/209/

Morgan-Short, K., Steinhauer, K., Sanz, C., \& Ullman, M. T. (2012). Explicit and implicit second language training differentially affect the achievement of native-like brain activation patterns. Journal of Cognitive Neuroscience, 24(4), 933-947. https://doi.org/10.1162/jocn_a_00119

Muthusamy, C., Mohamad, F., Ghazali, S., \& Subrayan, I. (2010). Enhancing ESL writing creativity via a literature-based language instruction. Studies in Language and Literature, 1(2), 36-47

Nachmanovitch, S. (1990). Free play: Improvisation in life and art. New York NY: Tarcher-Penguin.

Ntelioglou, B. (2011). 'But why do I have to take this class?' The mandatory drama-ESL class and multiliteracies pedagogy. The Journal of Applied Theatre and Performance, 16(1), 595-615. https://doi.org/10.1080/13569783.2011.617108

Pablo, J., \& Lasten, R. (2018). Writing difficulties and quality of academic Essays of Senior High School Students. Asia Pacific Journal of Multidisciplinary Research, 6(4), 46-57.

Paran, A. (2010). Testing the untestable in language education. Multilingual Matters, 17(1), 10-15. https://doi.org/10.21832/9781847692672

Randolph, P. (2014). Using creative writing as a bridge to enhance academic writing. Selected Proceedings of the 2011 Michigan Teachers of English to Speakers of Other Languages Conference Kalamazoo. Michigan, 11, $70-82$.

Schrijvers, M., Janssen, T., Fialho, O., \& Rijlaarsdam, G. (2016). The impact of literature education on students' perceptions of self and others: Exploring personal and social learning experiences in relation to teacher approach. L1-Educational Studies in Language and Literature, 17(1), 1-10. https://doi.org/10.17239/L1ESLL-2016.16.04.01

Scott, V. M. (2004). Cloze windows and aesthetic discoveries: Opening visions for teaching literature. The French Review, 78(2), 278.

Setyowati, I. (2016). Analyzing the students' ability in writing opinion essay using flash fiction. Journal of English Language Teaching and Linguistics, 1(79), 22-33. https://doi.org/10.21462/jeltl.v1i1.1

Shirzadi, G., \& Moheimany, M. (2018). Integrating literature into EFL classes: the case of bringing short stories into Iranian EFL classes to see its impact on the EFL learners' language learning motivation and their 
attitudes towards English literature. Language Teaching Research Quarterly, 5(1), 74-84.

Sivasubramaniam, S. (2006). Promoting the prevalence of literature in the practice of foreign and second language education: Issues and insights. Asian EFL Journal, 8(1), 254-273.

Spiro, J. (2014). Teaching poetry: Writing poetry-Teaching as a writer. English in Education, 41(3), 78-93. https://doi.org/10.1111/j.1754-8845.2007.tb01167.x

Tesdovska, E. (2016). Literature in ELT setting: students' attitudes and preferences towards literary texts. Procedia - Social and Behavioral Sciences, 232(1), 161-169. https://doi.org/10.1016/j.sbspro.2016.10.041

Van Peer, W. (2007). Introduction to foregrounding: A state of the art. Language and Literature, 16(2), 99-104. https://doi.org/10.1177/0963947007075978

Weber-Féve, S. (2009). Integrating language and literature: Teaching textual analysis with input and output activities and an input-to-output approach. Foreign Language Annals, 42(1), 453-467. https://doi.org/10.1111/j.1944-9720.2009.01035.x

Zhang, S. (2009). The role of input, interaction, and output in the development of oral fluency. English Language Teaching, 2(4), 91-100. https://doi.org/10.5539/elt.v2n4p91

Zyngier, S. (2006). Stylistics: Pedagogical applications. In K. Brown (Ed.), Encyclopedia of Language and Linguistics (2nd ed., pp. 226-232). Oxford: Elsevier. https://doi.org/10.1016/B0-08-044854-2/00549-6 


\section{Appendix A}

Writing Rubrics

\section{Cambridge English}

\section{Assessing Writing Performance - Level B1}

Writing assessment by examiners in the Cambridge English: Preliminary (PET), Preliminary (PET) for Schools and Business Preliminary exams (BEC)

Cambridge English writing scripts are marked by trained examiners in a secure online marking environment. The quality assurance of Writing Examiners (WEs) is managed by Team Leaders (TLS) who are in turn responsible to a Principal Examiner (PE). All of the examiners (PES, TLS and WES) must prove each year, through a certification process, that they are competent to assess. In addition, they are regularly monitored during live testing sessions.

The Writing Examiners award marks using a Writing Assessment Scale which was developed with explicit reference to the Common European Framework of Reference for Languages (CEFR). It covers all the levels of the Cambridge English exams and is divided into four subscales:

- Content

This focuses on how well the candidate has fulfilled the task, in other words, if they have done what they were asked to do.

- Communicative Achievement

This focuses on how appropriate the writing is for the task, and whether the candidate has used the appropriate register.

- Organisation

This focuses on the way the candidate puts together the piece of writing, in other words, if it is logical and ordered.

- Language

This focuses on vocabulary and grammar. It includes the range of language as well as how accurate it is.

Examiners use the $\mathrm{B} 1$ Level Assessment Scales to decide which marks to give candidates taking the Preliminary, Preliminary for Schools and Business Preliminary Writing test. 


\section{Cambridge English}

\section{The Assessment $\mathbf{S}$ cales}

The B1 Assessment Scales are divided into six bands from 0 to 5 , with 0 being the lowest and 5 the highest. Descriptors for each criterion are provided for bands 1,3 and 5 and indicate what a candidate is expected to demonstrate at each band. The descriptors for band 3 and above generally indicate performance of at least B1 level.

\begin{tabular}{|c|c|c|c|c|}
\hline B1 & CONTENT & $\begin{array}{l}\text { COMMUNICATIVE } \\
\text { ACHIEVEMENT }\end{array}$ & ORGANISATION & LANGUAGE \\
\hline 5 & $\begin{array}{l}\text { All content is relevant to the task. } \\
\text { Target reader is fuly informed. }\end{array}$ & $\begin{array}{l}\text { Uses the conventions of the } \\
\text { communicative task to hold } \\
\text { the target reader's attention } \\
\text { and communicate } \\
\text { stralghtorward ideas. }\end{array}$ & $\begin{array}{l}\text { Text is generally wel- } \\
\text { organised and coherent, using } \\
\text { a varlety of Inking words and } \\
\text { coheslve devices. }\end{array}$ & $\begin{array}{l}\text { Uses a range of everyday } \\
\text { vocabulary appropriately. } \\
\text { with occaslonal } \\
\text { Inappropriate use of less } \\
\text { common lex's. } \\
\text { Uses a range of simple and } \\
\text { some complex grammatical } \\
\text { forms with a good degree of } \\
\text { control. } \\
\text { Errors do not Impede } \\
\text { communication. }\end{array}$ \\
\hline 4 & \multicolumn{4}{|c|}{ Performance shares features of Bands 3 and 5 . } \\
\hline 3 & $\begin{array}{l}\text { Minor Irrelevances andior } \\
\text { omissions may be present. } \\
\text { Target reader is on the whole } \\
\text { Infomed. }\end{array}$ & $\begin{array}{l}\text { Uses the conventions of the } \\
\text { communicative task in } \\
\text { generally appropriate ways to } \\
\text { communicate stralghtorward } \\
\text { ldeas. }\end{array}$ & $\begin{array}{l}\text { Text is connected and } \\
\text { coherent, using basic Inking } \\
\text { words and a limited number of } \\
\text { coheslve devices. }\end{array}$ & $\begin{array}{l}\text { Uses everyday vocabulary } \\
\text { generaly appropriately, } \\
\text { Whle occaslonally overusing } \\
\text { certain lex's. } \\
\text { Uses simple grammatical } \\
\text { forms with a good degree of } \\
\text { control. } \\
\text { Whle errors are noticeable, } \\
\text { meaning can stll be } \\
\text { determined. }\end{array}$ \\
\hline 2 & \multicolumn{4}{|c|}{ Performance shares features of Bands 1 and 3 . } \\
\hline 1 & $\begin{array}{l}\text { Irrelevances and misinterpretation } \\
\text { of task may be present. } \\
\text { Target reader is minimally } \\
\text { Informed. }\end{array}$ & $\begin{array}{l}\text { Produces text that } \\
\text { communicates simple ideas in } \\
\text { simple ways. }\end{array}$ & $\begin{array}{l}\text { Text is connected using basic, } \\
\text { high-frequency Inking words. }\end{array}$ & $\begin{array}{l}\text { Uses basic vocabulary } \\
\text { reasonably appropriately. } \\
\text { Uses simple grammatical } \\
\text { forms with some degree of } \\
\text { control. } \\
\text { Errors may impede meaning } \\
\text { at times. }\end{array}$ \\
\hline 0 & $\begin{array}{l}\text { Content is totally Irnelevant. } \\
\text { Target reader is not infomed. }\end{array}$ & \multicolumn{3}{|c|}{ Performance below Band 1.} \\
\hline
\end{tabular}




\section{Appendix B:}

\section{Sample Lesson Plans}

\section{CONTROL GROUP}

\begin{tabular}{lllc}
\hline LESSON PLAN & & & \\
\hline Course Title & English for Business 2 & Week 2 & Session 1 \\
\hline Course Code & ENG 146 & Lesson/ Topic & Reading an Article Related to Outsourcing \\
\hline
\end{tabular}

\footnotetext{
Learning Outcomes

- $\quad$ Note specific details of a written discourse related to outsourcing

- $\quad$ Paraphrase and summarize ideas of a written discourse related to outsourcing.

- $\quad$ Construct judgments and propose ideas from a given written
} discourse related to outsourcing.

\begin{tabular}{|c|c|}
\hline Time & Instructional Activities \\
\hline \multirow[t]{3}{*}{15 minutes } & Task 1: Preparation Activity \\
\hline & 1. First, the students are presented with the word: OUTSOURCING. \\
\hline & $\begin{array}{l}\text { 2. Then, the students are directed to the next activity, which is to brainstorm about the concept. Their } \\
\text { ideas will be discussed in class which will be facilitate by the teacher. }\end{array}$ \\
\hline \multirow[t]{3}{*}{15 minutes } & Task 2: Formal Reading Subtask: Noting Details \\
\hline & $\begin{array}{l}\text { 1. The students are required to silently read selected paragraphs from their coursebook. } \\
\text { 2. In selected junctures of the reading passage from their coursebook, the teacher stops the students } \\
\text { and leads them to a comprehension check that focuses on the students' ability to note details and other } \\
\text { information from the text. }\end{array}$ \\
\hline & 3. The said process is repeated until all paragraphs are processed with the teacher as the facilitator. \\
\hline \multirow[t]{4}{*}{20 minutes } & Task 3: Formal Reading Subtask: Paraphrasing and Summarizing Ideas \\
\hline & $\begin{array}{l}\text { 1. At this point, the teacher leads the students to a higher cognitive task, which is to paraphrase and } \\
\text { summarize ideas from the reading passage. }\end{array}$ \\
\hline & $\begin{array}{l}\text { 2. In order to do this, the teacher selects a sentence from each of the paragraphs and asks the students } \\
\text { to paraphrase the sentence using their own words. This can be done by groups. }\end{array}$ \\
\hline & $\begin{array}{l}\text { 3. Part of this subtask is to summarize each of the paragraphs of the reading passage. A group is } \\
\text { assigned to a specific paragraph for them to summarize and present their work to the class. }\end{array}$ \\
\hline \multirow[t]{4}{*}{20 minutes } & Task 4: Formal Reading Subtask: Construct and Propose Judgments \\
\hline & $\begin{array}{l}\text { 1. In this task, the students are regrouped in order to construct and propose judgments related to the } \\
\text { article they have just read. }\end{array}$ \\
\hline & $\begin{array}{l}\text { 2. The teacher presents a problem related to the main topic of the reading passage and she asks the } \\
\text { students to propose solutions as a group. }\end{array}$ \\
\hline & $\begin{array}{l}\text { 3. Each group discusses their proposed solutions to the problem presented and they present these } \\
\text { solutions to the class for plenary processing. }\end{array}$ \\
\hline \multirow[t]{4}{*}{20 minutes } & Task 5: Evaluation and Generalization \\
\hline & $\begin{array}{l}\text { 1. The last part of this instructional session is the process of evaluation and generalization } \\
\text { on the part of the students which is facilitated by the teacher. }\end{array}$ \\
\hline & $\begin{array}{l}\text { 2. The teacher requires the students to read a short passage related to outsourcing found on } \\
\text { their workbook. }\end{array}$ \\
\hline & $\begin{array}{l}\text { 3. Then the students later answer reading comprehension questions on noting details, } \\
\text { paraphrasing or summarizing ideas, and constructing judgments or proposing ideas. }\end{array}$ \\
\hline
\end{tabular}

\section{EXPERIMENTAL GROUP}

\begin{tabular}{lllc}
\hline LESSON PLAN & & & \\
\hline Course Title & English for Business 2 & Week 2 & Session 1 \\
\hline Course Code & ENG 146 & Lesson/ Topic & Reading an Article Related to Outsourcing \\
\hline
\end{tabular}




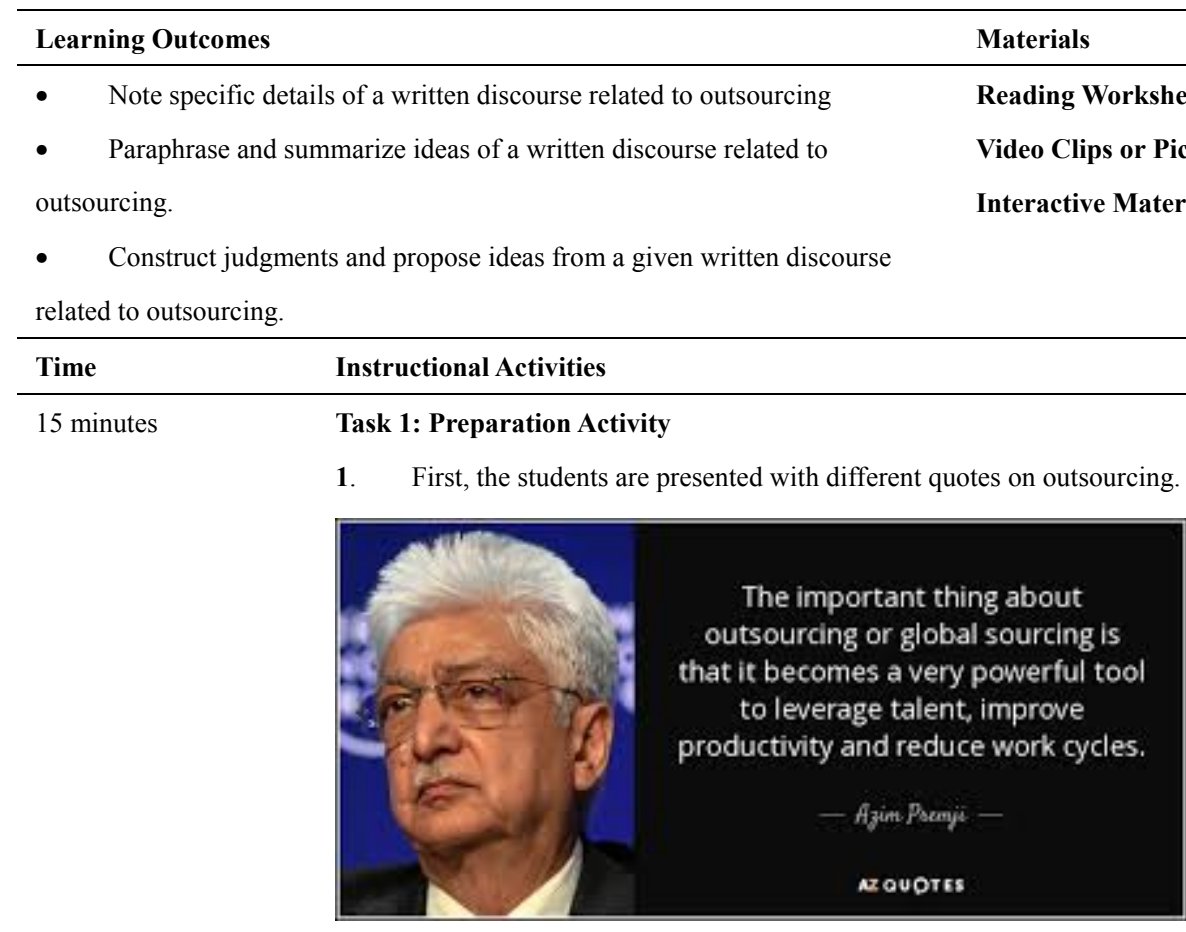
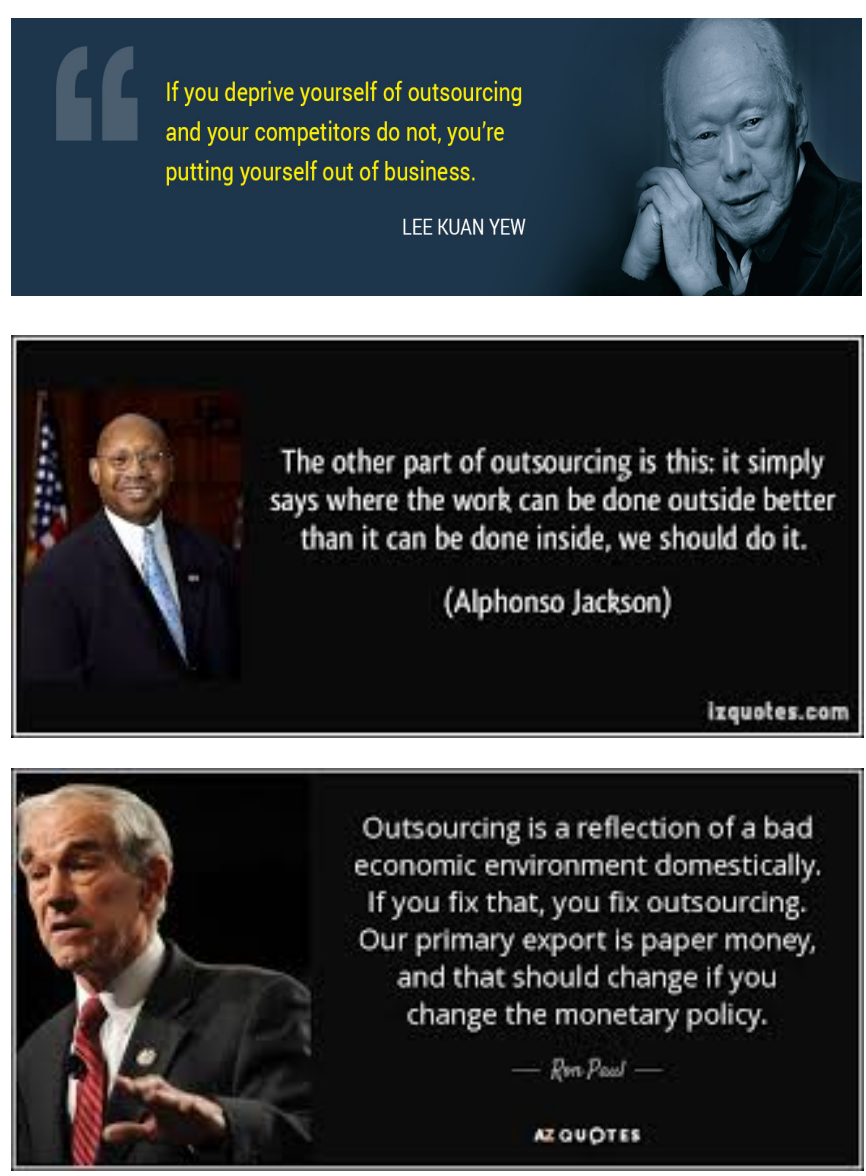

2. Then, the students are directed to the next activity, which is to brainstorm and discuss about the quotes. The class is divided into small groups. Each group chooses a quote and explain it in the class. 
1. The students are required to silently read selected paragraphs from their coursebook.

2. In selected junctures of the reading passage from their coursebook, the teacher stops the students and leads them to a comprehension check that focuses on the students' ability to note details and other information from the text.

3. The said process is repeated until all paragraphs are processed with the teacher as the facilitator.

20 minutes

20 minutes

20 minutes

\section{Task 3: Formal Reading Subtask: Paraphrasing and Summarizing Ideas}

1. At this point, the teacher leads the students to a higher cognitive task, which is to paraphrase and summarize ideas from the reading passage.

2. In order to do this, the teacher selects a sentence from each of the paragraphs and asks the students to paraphrase the sentence using their own words. This can be done by groups.

3. Part of this subtask is to summarize each of the paragraphs of the reading passage. A group is assigned to a specific paragraph for them to summarize and present their work to the class.

\section{Task 4: Formal Reading Subtask: Construct and Propose Judgments}

1. In this task, the students are regrouped in order to construct and propose judgments related to the article they have just read.

2. The teacher presents a problem related to the main topic of the reading passage and she asks the students to propose solutions as a group.

3. Each group discusses their proposed solutions to the problem presented and they present these solutions to the class for plenary processing.

Task 5: Evaluation and Generalization

1. The last part of this instructional session is the process of evaluation and generalization on the part of the students which is facilitated by the teacher.

2. The teacher requires the students to read a short passage related to outsourcing found on their workbook.

3. Then the students later answer reading comprehension questions on noting details, paraphrasing or summarizing ideas, and constructing judgments or proposing ideas. 


\section{Appendix C:}

\section{Writing Samples}

Before the Experiment

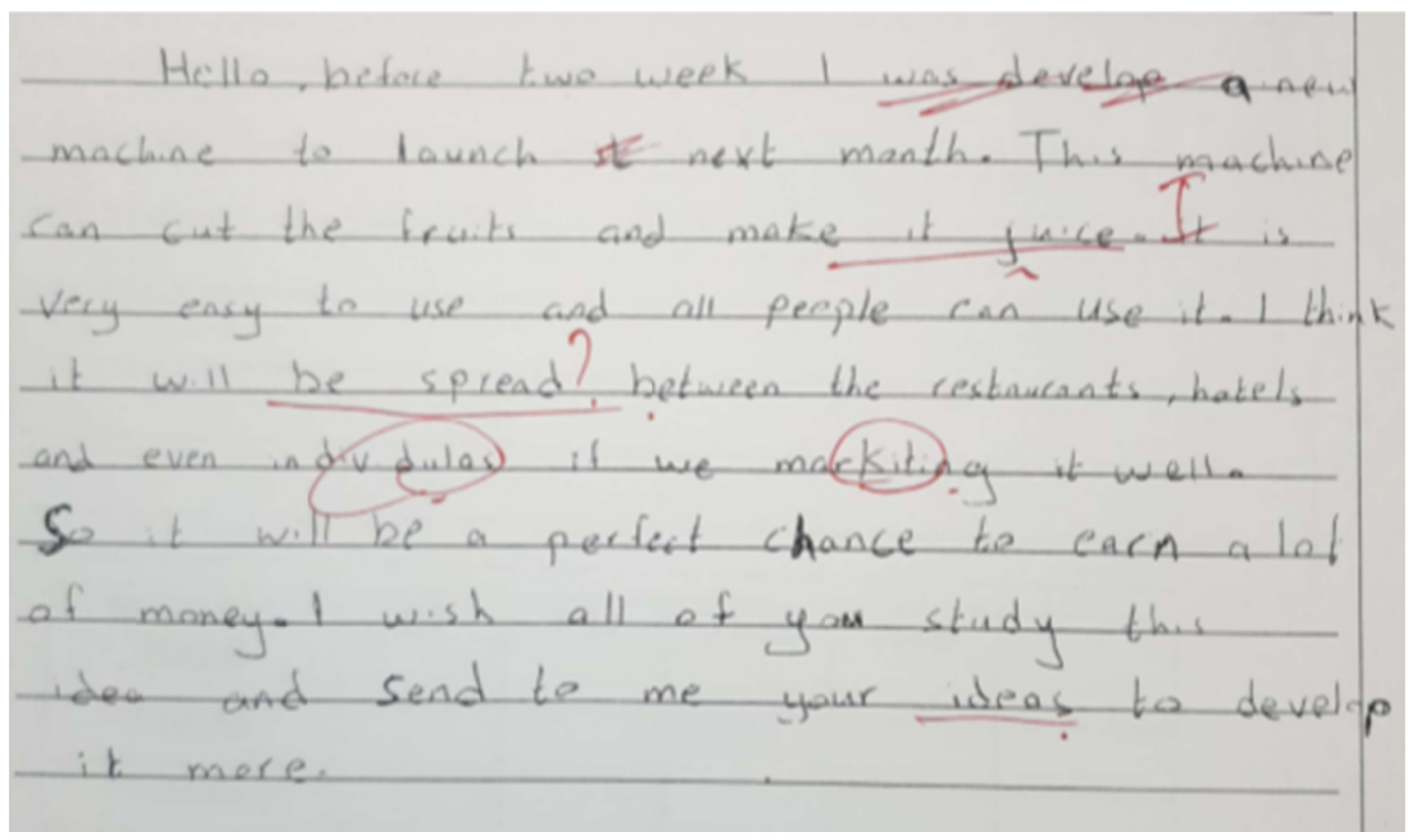

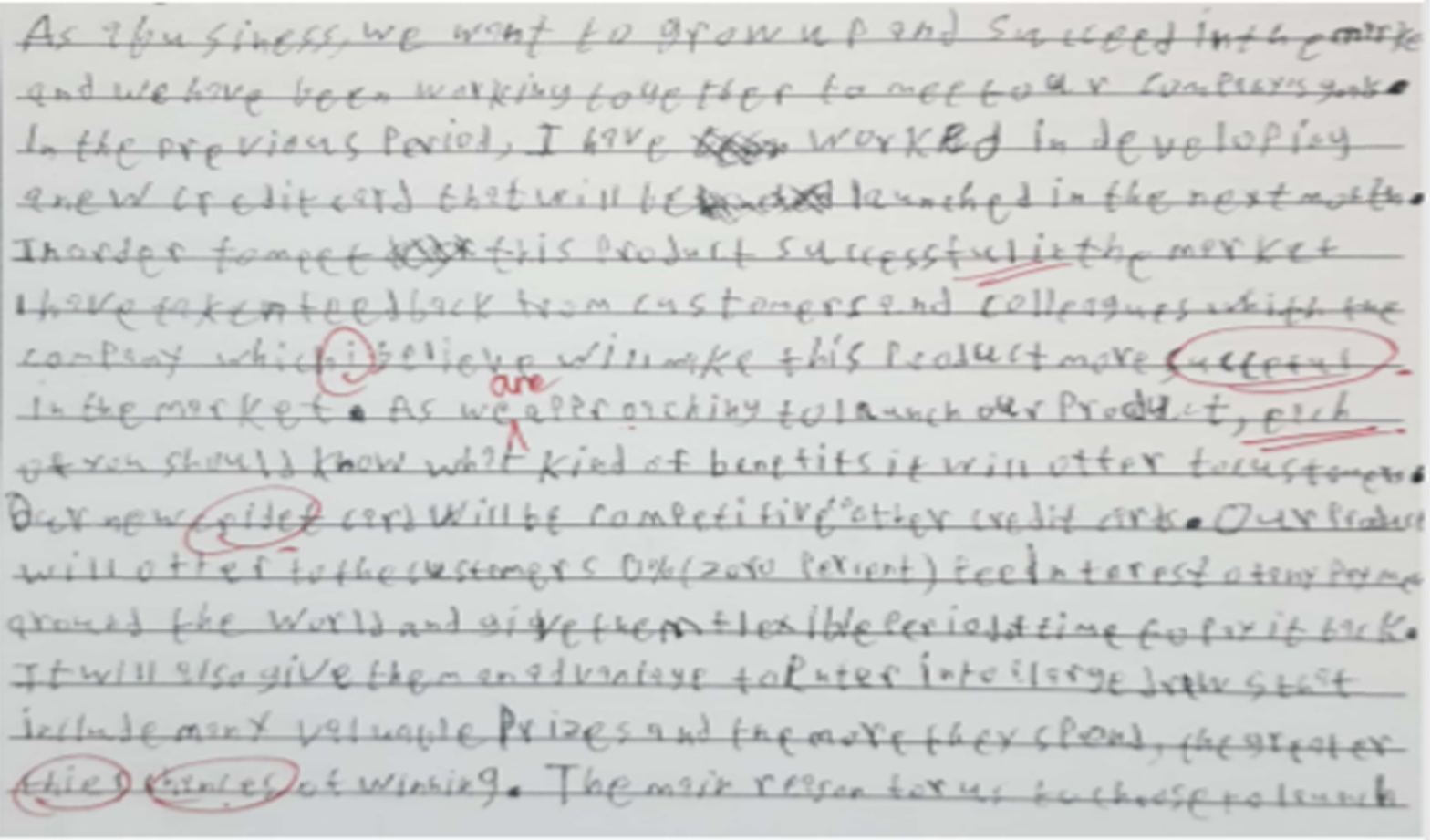




\section{After the Experiment}

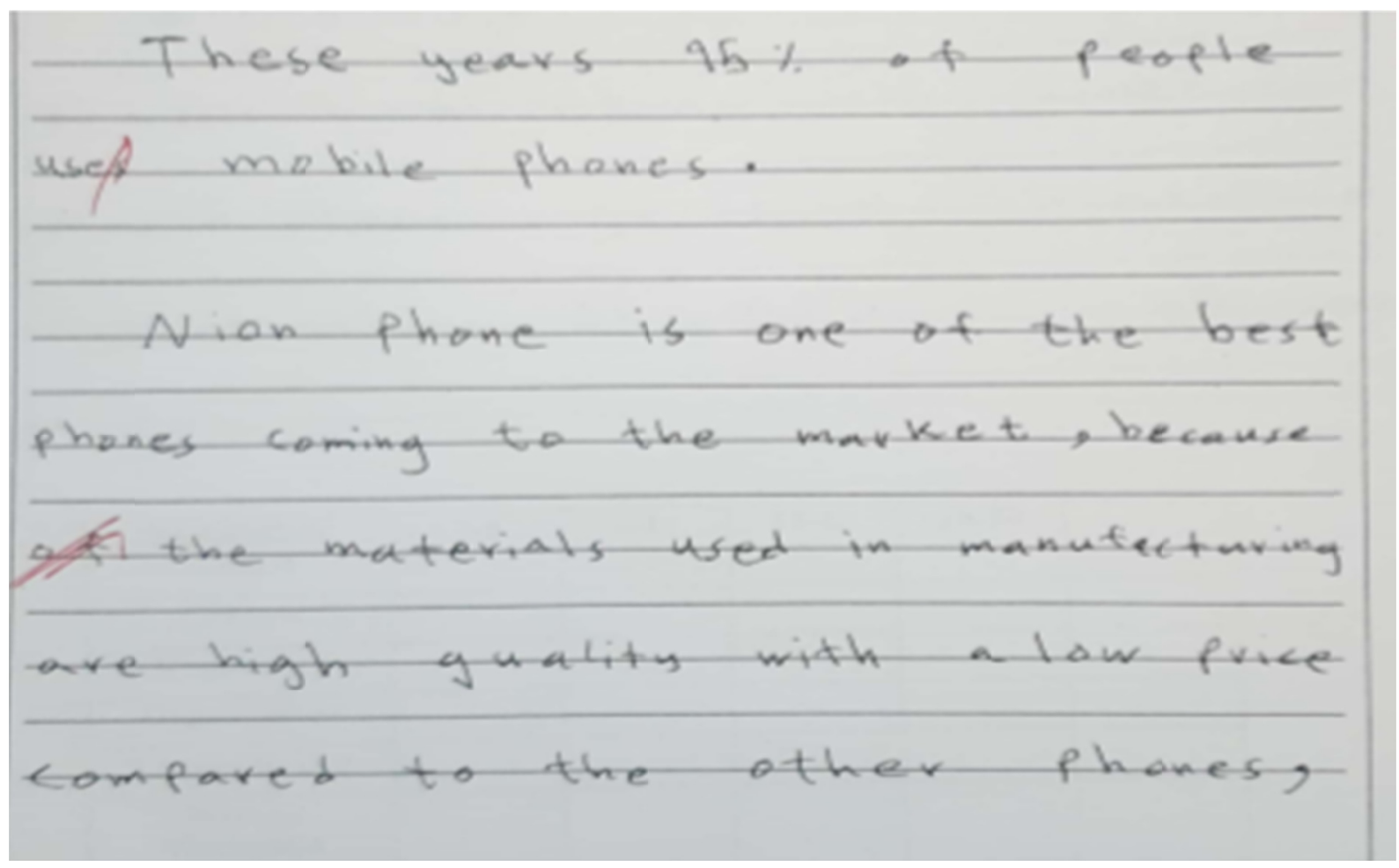

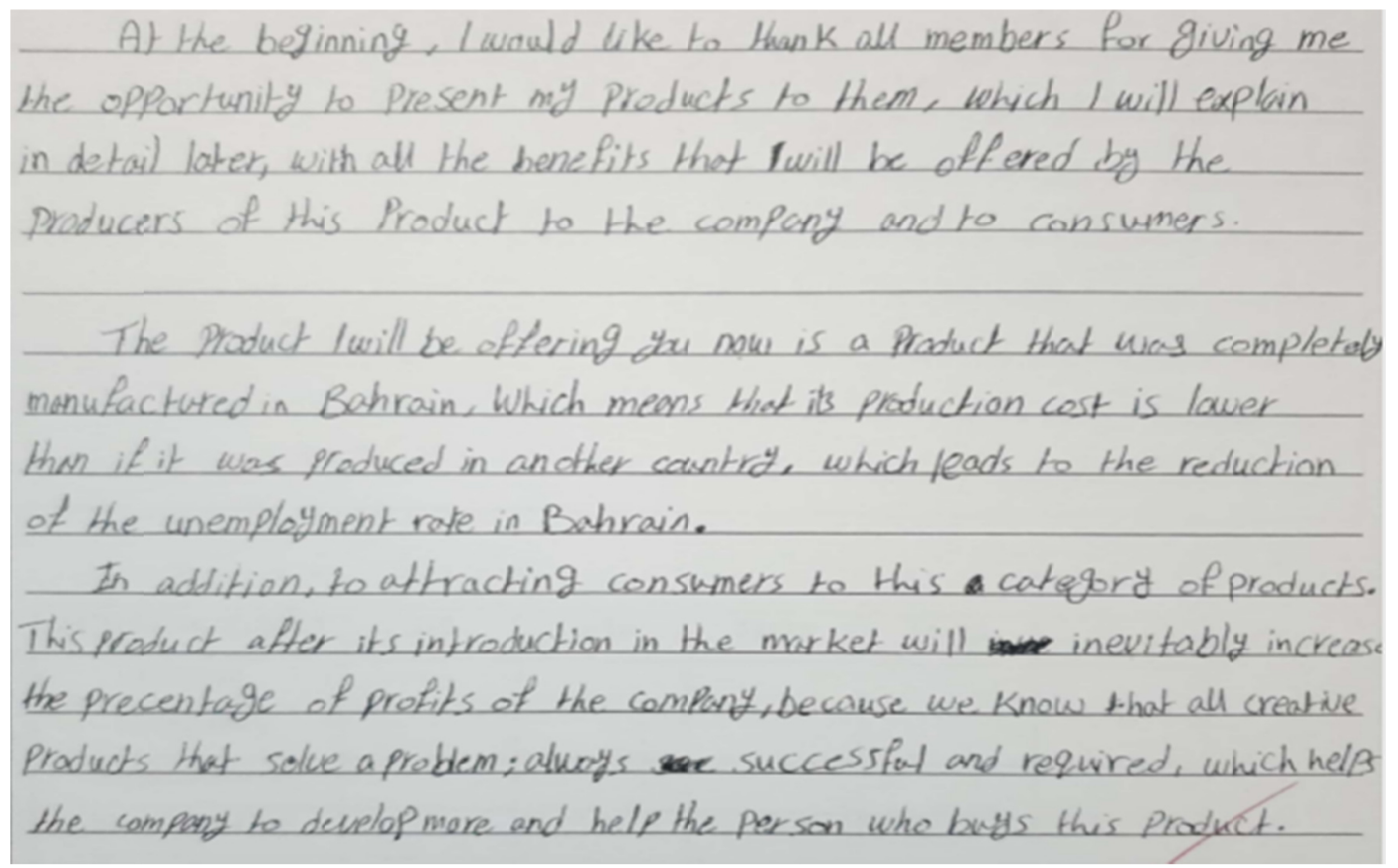

\section{Copyrights}

Copyright for this article is retained by the author, with first publication rights granted to the journal.

This is an open-access article distributed under the terms and conditions of the Creative Commons Attribution license (http://creativecommons.org/licenses/by/4.0/). 